\title{
Effectiveness of Arbuscular Mycorrhizal Fungal Isolates from the Land Uses of Amazon Region in Symbiosis with Cowpea
}

\author{
GLÁUCIA ALVES E SILVA ${ }^{1}$, JOSÉ O. SIQUEIRA ${ }^{1,2}$, SIDNEY L. STÜRMER ${ }^{3}$ and FATIMA M.S. MOREIRA ${ }^{1}$ \\ ${ }^{1}$ Departamento de Ciências do Solo/DCS, Universidade Federal de Lavras/ \\ UFLA, Caixa Postal 3037, 37200-000 Lavras, MG, Brazil \\ ${ }^{2}$ Instituto Tecnológico Vale, Rua Boaventura da Silva, 955, Nazaré, 66055-090 Belém, PA Brazil \\ ${ }^{3}$ Departamento de Ciências Naturais/DCN, Universidade Regional de Blumenau/ \\ FURB, Caixa Postal 1507, 89010-971 Blumenau, SC, Brazil
}

Manuscript received on April 5, 2016; accepted for publication on May 26, 2016

\begin{abstract}
Arbuscular mycorrhizal fungi provide several ecosystem services, including increase in plant growth and nutrition. The occurrence, richness, and structure of arbuscular mycorrhizal fungi communities are influenced by human activities, which may affect the functional benefits of these components of the soil biota. In this study, 13 arbuscular mycorrhizal fungi isolates originating from soils with different land uses in the Alto Solimões-Amazon region were evaluated regarding their effect on growth, nutrition, and cowpea yield in controlled conditions using two soils. Comparisons with reference isolates and a mixture of isolates were also performed. Fungal isolates exhibited a wide variability associated with colonization, sporulation, production of aboveground biomass, nitrogen and phosphorus uptake, and grain yield, indicating high functional diversity within and among fungal species. A generalized effect of isolates in promoting phosphorus uptake, increase in biomass, and cowpea yield was observed in both soils. The isolates of Glomus were the most efficient and are promising isolates for practical inoculation programs. No relationship was found between the origin of fungal isolate (i.e. land use) and their symbiotic performance in cowpea.
\end{abstract}

Key words: biodiversity, Inceptisol, Oxisol, root colonization, Vigna unguiculata.

\section{INTRODUCTION}

Arbuscular mycorrhizal fungi (AMF - Phylum Glomeromycota) are important components of terrestrial ecosystems where they have a pivotal role in providing several ecosystem services (Gianinazzi et al. 2010). The mycorrhizal colonization of the root cortex and the external mycelia produced in

Correspondence to: Fatima Maria de Souza Moreira

E-mail: fmoreira@dcs.ufla.br the soil by AMF act as access routes for plants to uptake low-mobility nutrients, including phosphorus $(\mathrm{P})$, resulting in increased nutrient absorption and often plant growth (Smith and Read 2008). Similar to other components of the soil biota, changes in land use can modify AMF community structure and richness (Stürmer and Siqueira 2011) and consequently compromise the benefits of AMF to these communities. 
Although AMF have no host specificity, these fungi can exhibit different degrees of symbiotic compatibility with host plants, which are affected by host and fungal genotype (Van der Heijden et al. 1998, Smith et al. 2000), and environmental factors (Koide 1991). Furthermore, large functional variability among distinct AMF species and fungal isolates (=lineages) of the same species (Klironomos 2003, Smith et al. 2000, 2004) have been demonstrated. Munkvold et al. (2004) argue that intraspecific variations are of great ecological importance, particularly in situations with low species diversity, considering that a high intraspecific functional diversity could compensate for the low species diversity with regard to the symbiotic effectiveness of AMF. However, these variations are poorly known, particularly considering AMF isolates originating from tropical soils.

Thonar et al. (2011) observed distinct spatial efficiencies in $\mathrm{P}$ uptake by Rhizophagus intraradices, Claroideoglomus claroideum, and Gigaspora margarita, which help to explain the empirical evidence that root colonization by multiple AMF species may be more beneficial to plants than colonization by a single species (Jansa et al. 2008). However, there is evidence that most of the benefits to host plants could be achieved using a single species, provided that the species is efficient and adapted (Daft and Hogarth 1983, Edathil et al. 1996). Therefore, a high taxonomic diversity of AMF species in a particular system would not necessarily result in increased benefits to the host plants. Another important aspect is related to the interaction of different isolates with their host species. Santos et al. (2008) observed varying degrees of effectiveness of AMF isolates, depending on the host species evaluated, and observed that mixtures of isolates were the most efficient fungal treatments. Fungal isolates pertaining to different species from the same mycorrhizal community exhibited distinct efficiencies in promoting the accumulation of leaf biomass and phosphorus content in soybean and red clover, but at least one isolate of each community was efficient in promoting plant growth and nutrition (Stürmer 2004).

Despite the geographic extent and the high plant species richness detected in the Amazon tropical forest, only recently the composition of AMF species from distinct land use systems has been accessed (Leal et al. 2009, 2013, Stürmer and Siqueira 2011, Freitas et al. 2014) and on the functional diversity of AMF communities (Silva et al. 2009). Amazon soils exhibit high richness of AMF species, and 61 morphotypes have been reported to occur in soils under different land uses in the Western Amazon region, of which $30 \%$ represent undescribed species (Stürmer and Siqueira 2011). Studies on the inter and intraspecific variation about the effectiveness of AMF to promote plant growth have been done mainly with fungal isolates from temperate countries under temperate conditions (Munkvold et al. 2004, Koch et al. 2004, Antunes et al. 2011, Mensah et al. 2015). In tropical region, Siqueira et al. (1998) found high intra-specific variation on effectiveness among isolates of Claroideoglomus etunicatum when inoculated in coffee plants.

Fungal communities originating from distinct land use system in the Brazilian Amazon region screened for their effectiveness had contrasting effectiveness in promoting plant growth and nutrition of cowpea, indicating the presence of efficient fungal lineages within each community that can be selected for inoculation programs (Silva et al. 2009). In this study, fungal isolates belonging to distinct genera and species established in single cultures from these communities were compared according to their effectiveness in two types of soils. Cowpea was selected as the host plant because of its importance as cash and food crop in the Amazon region and other tropical countries. The following hypothesis were tested: 1) difference 
in effectiveness is related to the taxonomic position and origin (land use) of the fungal isolates, and 2) isolate effectiveness varies according to soil type.

\section{MATERIALS AND METHODS}

The study was conducted in a greenhouse in two sequential stages, each comprising two soil types with different physical and chemical characteristics. Stage 1 was conducted for 120 days in order to evaluate grain yield, mycorrhizal root colonization and AMF spore number. Once plants of stage 1 were harvested, cowpea seeds were sown into the same containers with the same treatments to start stage 2 in order to evaluate nodulation by rhizobia, plant growth (shoot dry matter) and nutrition ( $\mathrm{P}$ and $\mathrm{N}$ content and accumulation) and mycorrhizal root colonization. Stage 2 was required for the following reasons: 1) logistic problem to sample and transport large amounts of the "Amazon soil", as this soil came from the western Amazon region, about 5,000 km from where the experiments were conducted, and 2) evaluation of cowpea yield is at the end of the plant growth cycle when the plant is completely dried, precluding the evaluation of nodulation and shoot nutrients, that are commonly evaluated at the flowering stage.

The soil designated "Amazon soil" was a typical haplic, aluminous Inceptisol with a clayey texture, collected from a depth of $0-20 \mathrm{~cm}$ in a pasture land covered with imperial grass. This area was originally covered by equatorial evergreen forest and is located in the city of Benjamin Constant, Amazonas state, Brazil. Amazon soil physical and chemical characteristics are described by Moreira et al. (2009). After the incubation period with dolomitic limestone to raise the base saturation, the Amazon soil was fumigated with methyl bromide (98\% methyl bromide $+2 \%$ chloropicrin) at a dose of $393 \mathrm{~cm}^{3} \cdot \mathrm{m}^{-3}$ After liming, soil contained the following chemical characteristics: $\mathrm{pH}$ in water $=6.2 ; \mathrm{P}$ content $=4.9 \mathrm{mg} . \mathrm{dm}^{-3}($ Mehlich- 1$) ; \mathrm{K}^{+}$ content $=86 \mathrm{mg} \cdot \mathrm{dm}^{-3}($ Mehlich -1$) ; \mathrm{Ca}^{+2}$ content $=7.8$ $\mathrm{cmol}_{\mathrm{c}} \cdot \mathrm{dm}^{-3} ; \mathrm{Mg}^{+2}$ content $=3.9 \mathrm{cmol}_{\mathrm{c}} \cdot \mathrm{dm}^{-3} ; \mathrm{Al}^{+3}$ content $=0.0 \mathrm{cmol}_{\mathrm{c}} \cdot \mathrm{dm}^{-3} ; \mathrm{H}+\mathrm{Al}$ content $=2.6 \mathrm{cmol}_{\text {c }}$. $\mathrm{dm}^{-3} ; \mathrm{V}=82.1 \%$, and $\mathrm{OM}=3.3$ dag. $\mathrm{kg}^{-1}$. The soil designated "Lavras soil" was a substrate composed of sterile sand mixed with a red-yellow latosol (Oxisol) (1:2, vol/vol) with a clayey texture, collected from the $0-20 \mathrm{~cm}$ layer from a native forest located on the campus of the Universidade Federal de Lavras/UFLA, in Lavras, Minas Gerais state, Brazil. Chemical characteristics after soil liming were: $\mathrm{pH}$ in water $=5.9 ; \mathrm{P}=4.9 \mathrm{mg} \mathrm{dm}^{-3}$ (Mehlich-1); $\mathrm{K}^{+}=50 \mathrm{mg} \mathrm{dm}{ }^{-3}$ (Mehlich -1); $\mathrm{Ca}^{2+}$ $=1.7 \mathrm{cmol}_{\mathrm{c}} \mathrm{dm}^{-3} ; \mathrm{Mg}^{2+}=0.9 \mathrm{cmol}_{\mathrm{c}} \mathrm{dm}^{-3} ; \mathrm{Al}^{3+}$ $=0.0 \mathrm{cmol}_{\mathrm{c}} \mathrm{dm}^{-3} ; \mathrm{H}+\mathrm{Al}=2.6 \mathrm{cmol}_{\mathrm{c}} \mathrm{dm}^{-3} ; \mathrm{V}=$ $51.2 \%$ and $\mathrm{OM}=2.1 \mathrm{dag}^{-1}$. After liming and fumigation, both soils were transferred to $3.0 \mathrm{dm}^{3}$ plastic containers.

The experimental design incorporated randomized blocks with 2 plants per container and 5 replicates. The study comprised 23 fungal treatments: 13 isolates from different land uses in the Amazon region, 3 reference isolates obtained from the culture collection of UFLA, and 6 artificial communities made up by mixing fungal isolates from the same land use, and 1 noninoculated control (Table I). Glomus sp11 and Glomus sp14 could not be identified to species level. Glomus sp11 forms spores with $63 \mu \mathrm{m}$ diameter with a spore wall formed by an outer sloughing layer and a laminated layer formed by one lamina $0.6 \mu \mathrm{m}$ thick, resembling Glomus minutum. Glomus sp14 differentiates a spore wall formed by an evanescent outer layer up to $2 \mu \mathrm{m}$ thick and a finely laminated layer 6-7 $\mu \mathrm{m}$ thick. Spore color is cream yellow and subtending hypha near the spore has laminated layer $2 \mu \mathrm{m}$ thick which extends down to the hyphae and gets thinner, resembling G. versiforme. Reference isolates were single cultures of Claroideoglomus etunicatum (Ce), Rhizophagus clarus (Rc), and Gigaspora margarita $(\mathrm{Gm})$. The 6 artificial communities 
TABLE I

List of the AMF fungal species and isolates used for the efficiency experiment with cowpea.

\begin{tabular}{|c|c|}
\hline Identification code & Species \\
\hline Ad-F* & Acaulospora delicata \\
\hline Ad-CV & Acaulospora delicata \\
\hline $\mathrm{Am}-\mathrm{CV}$ & Acaulospora morrowiae \\
\hline G11-CV & Glomus sp. 11 \\
\hline G11-CN & Glomus sp. 11 \\
\hline G14-CN & Glomus sp. 14 \\
\hline Ad-AF & Acaulospora delicata \\
\hline G11-AF & Glomus sp. 11 \\
\hline G14-AF & Glomus sp. 14 \\
\hline Am-R & Acaulospora morrowiae \\
\hline Ad-R & Acaulospora delicata \\
\hline G11-P & Glomus sp.11 \\
\hline Ad-P & Acaulospora delicata \\
\hline $\mathrm{Ce}$ & Claroideoglomus etunicatum \\
\hline $\mathrm{Rc}$ & Rhizophagus clarus \\
\hline $\mathrm{Gm}$ & Gigaspora margarita \\
\hline $\mathrm{M}-\mathrm{CN} * *$ & Glomus sp.11+Glomus sp.14 \\
\hline $\mathrm{M}-\mathrm{CV}$ & Acaulospora delicata + Acaulospora morrowiae + Glomussp. 11 \\
\hline $\mathrm{M}-\mathrm{AF}$ & Acaulospora delicata + Glomus sp. $11+$ Glomus sp. 14 \\
\hline M-R & Acaulospora delicata + Acaulospora morrowiae \\
\hline M-P & Glomus sp. $11+$ Acaulospora delicata \\
\hline MT & $\begin{array}{l}\text { Ad-F-Acaulospora delicata + G11-P-Glomus sp. } 11+\text { G14-CN-Glomus sp.14+ } \\
\text { Am-R-Acaulospora morrowiae }\end{array}$ \\
\hline
\end{tabular}

*F - Forest; CV - Capoeira Velha (old secondary forest); CN - Capoeira Nova (Young secondary forest); AF - Agroforest; R crop; P - Pasture; **All artificial communities (M) were supplemented with single cultures of: Claroideoglomus etunicatus (Ce), Rhizophagus clarus $(\mathrm{Rc})$ and Gigaspora margarita $(\mathrm{Gm})$; MT - Isolates mixtures with the diverse species from Amazon region.

were supplemented with a mixture of the reference isolates. AMF spores recovered from trap cultures established with soil from distinct land use systems with Sorghum sudanense and Vigna unguiculata as hosts (Leal et al. 2009) were extracted by wet sieving following a centrifugation step using water and a sucrose solution of 500 g.L $\mathrm{L}^{-1}$ (Gerdemann and Nicolson 1963) and used to establish single cultures. Stocks of these cultures were later propagated under greenhouse conditions at UFLA using pueraria (Pueraria phaseoloides) and brachiaria (Brachiaria decumbens) as hosts for 150 days.

Cowpea (Vigna unguiculata L. cv. BRS 17 Gurgueia) is a variety resistant to the cowpea golden mosaic virus (CpGMV) and was provided by Embrapa Meio Norte, located in Teresina, Piauí, Brazil. Seeds were pre-germinated on filter paper in germination chambers. At the moment that seedlings were transferred to containers filled with $3.0 \mathrm{dm}^{3}$ of each soil, they were inoculated with a suspension of AMF spores (approximately 250 spores per container) for each inoculation treatment, in addition to the non-inoculated controls (NI). For the artificial communities treatment, the total number of spores was equally divided by the number of AMF species comprising this inoculum. All treatments were inoculated with $1 \mathrm{~mL}$ of Bradyrhizobium sp., strain INPA03-11B containing 
$10^{9}$ viable rhizobial cells $\mathrm{mL}^{-1}$. To standardize the microbiota between the inoculated treatments and NI, $10 \mathrm{~mL}$ of a filtered inoculum without AMF spores was added to each container of the control group. Twenty days after transferring the pre-germinated seedlings to the containers, $20 \mathrm{~mL}$ of a Hoagland and Arnon (1950) solution without $\mathrm{P}$ or $\mathrm{N}$, was applied every 20 days. The nutrient mixture applied per container contained $14.0 \mathrm{mg}$ of potassium, $5.8 \mathrm{mg}$ of magnesium, $9.53 \mathrm{mg}$ of calcium, $20.9 \mathrm{mg}$ of sulphur, $61.0 \mu \mathrm{g}$ of boron, and $1.28 \mu \mathrm{g}$ of molybdenum. Irrigation was performed to maintain the soil moisture at $60 \%$ of the total pore volume (TPV) filled with water.

After 120 days of growth, between November 2007 and March 2008 (stage 1), plants were removed from the containers and separated into shoots and roots. After washing the roots, approximately $1.0 \mathrm{~g}$ of fresh roots was removed from each plant for clearing and staining (Phillips and Hayman 1970) and subsequent evaluation of mycorrhizal colonization (Giovannetti and Mosse 1980). The pods from each plant were air dried. The plant seeds were harvested when the pods were ripe (yellow colour) and the grain yield per container was determined after drying in a forced air oven at $60{ }^{\circ} \mathrm{C}$ until constant weight. Spore extraction was performed by wet sieving and sucrose centrifugation as described above and counted under a dissecting microscope at $20 \mathrm{x}$ to 40x magnification to determine the spore density per $50 \mathrm{~mL}$ of soil for all the AMF-inoculated treatments.

Stage 2 was conducted for 85 days (April to July 2008) until flowering after harvesting plants of stage 1. Plants were inoculated with Bradyrhizobium $\mathrm{sp}$., and received the same amount of the nutrient solution without $\mathrm{N}$ and $\mathrm{P}$ as for stage 1 . The total nutrient mixture applied per container contained $9.33 \mathrm{mg}$ of potassium, $3.85 \mathrm{mg}$ of magnesium, 6.41 $\mathrm{mg}$ of calcium, $14.00 \mathrm{mg}$ of sulphur, $40.67 \mu \mathrm{g}$ of boron, and $0.85 \mu \mathrm{g}$ of molybdenum. Irrigation was performed to maintain the soil moisture at $60 \%$ of the total pore volume (TPV) filled with water.

At harvest, plants were removed from the containers, and shoots separated from roots. After washing the roots, the number and weight of nodules were determined, and approximately $1.0 \mathrm{~g}$ of fresh roots was removed from each plant for assessment of mycorrhizal colonization as in stage 1 . The plant material was dried in an oven with forced air circulation at $60{ }^{\circ} \mathrm{C}$ until a constant weight was achieved, and shoot dry mass (SDM) was determined. The SDM was ground and chemically analysed to determine the levels of $\mathrm{N}$ and P, according to Zarosky and Burau (1977).

Data from the stages 1 and 2 were subjected to analysis of variance and means were separated using the Scott-Knott test, at a 5\% confidence interval using the Sisvar statistical software (Ferreira 2011). Values of mycorrhizal colonization, nodulation, and sporulation previously transformed via arc sin $(\mathrm{x} / 100)^{1 / 2},(\mathrm{x}+1)^{1 / 2}$, and $\log (1+\mathrm{x})$, respectively.

\section{RESULTS}

\section{ROOT COLONIZATION AND SPORULATION}

Considering stages 1 and 2 of the experiment, mycorrhizal colonization of cowpea ranged from $1 \%$ to $82 \%$, according to the fungal treatment, with an overall mean of $32 \%$ and $33 \%$ for the Amazon and Lavras soils, respectively (Table II). In the Lavras and Amazon soil, 60\% and 45\% of the inoculated plants, respectively, exhibited a mycorrhizal colonization higher than $20 \%$. No evidence of colonization was observed in plants of the NI treatment in either soil type or stage. Among the fungal treatments, only the Ad-F isolate did not colonize roots in either of the two stages in the Amazon soil, whereas the root colonization by this isolate was $>10 \%$ in the Lavras soil. In the Amazon soil, at stage 2, the Am-CV and G11-CV isolates did not colonize the plant roots and did not differ from the Ad-F, Ad-CV, G14-AF, Am-R, and Ad-R 
TABLE II

Mycorrhizal colonization of cowpea 120 days after inoculation (DAI - stage 1) with diverse treatments of inoculation of arbuscular mycorrhizal fungi (AMF) and 85 days after harvest of stage 1and new planting (stage 2), and spores number 120 DAI - stage 1, in Amazon and Lavras soils.

\begin{tabular}{|c|c|c|c|c|c|c|}
\hline \multirow{3}{*}{$\begin{array}{c}\text { Treatments } \\
\text { (AMF isolates)* }\end{array}$} & \multicolumn{2}{|c|}{ Colonization stage 1} & \multicolumn{2}{|c|}{ Colonization stage 2} & \multicolumn{2}{|c|}{ Spores number stage 1} \\
\hline & Amazon soil & Lavras soil & Amazon soil & Lavras soil & Amazon soil & Lavras soil \\
\hline & \multicolumn{4}{|c|}{$\%$} & \multicolumn{2}{|c|}{$50 \mathrm{~mL}$ of soil } \\
\hline Ad-F & $0 \mathrm{~d}$ & $10 \mathrm{c}$ & $0 \mathrm{~d}$ & $3 \mathrm{~d}$ & $219 b$ & $3,170 \mathrm{~b}$ \\
\hline Ad-CV & $5 \mathrm{~d}$ & $4 \mathrm{c}$ & $1 \mathrm{~d}$ & $6 \mathrm{~d}$ & $709 \mathrm{a}$ & $1,538 \mathrm{c}$ \\
\hline $\mathrm{Am}-\mathrm{CV}$ & $2 \mathrm{~d}$ & $4 \mathrm{c}$ & $0 \mathrm{~d}$ & $4 \mathrm{~d}$ & $511 \mathrm{a}$ & $703 \mathrm{~d}$ \\
\hline G11-CV & $1 \mathrm{~d}$ & $39 \mathrm{a}$ & $0 \mathrm{~d}$ & $22 \mathrm{c}$ & $610 \mathrm{a}$ & $3,018 \mathrm{~b}$ \\
\hline G11-CN & $47 \mathrm{~b}$ & $71 \mathrm{a}$ & $54 \mathrm{~b}$ & $42 \mathrm{~b}$ & $30 \mathrm{c}$ & $8,510 \mathrm{a}$ \\
\hline G14-CN & $26 \mathrm{c}$ & $28 \mathrm{~b}$ & $60 \mathrm{~b}$ & $76 \mathrm{a}$ & 379 a & $1,580 \mathrm{c}$ \\
\hline Ad-AF & $16 \mathrm{c}$ & $14 \mathrm{~b}$ & $10 \mathrm{c}$ & $25 \mathrm{c}$ & $2,899 \mathrm{a}$ & 10,645 a \\
\hline G11-AF & $5 \mathrm{~d}$ & $3 \mathrm{c}$ & $8 \mathrm{c}$ & $6 \mathrm{~d}$ & $40 \mathrm{c}$ & $3,376 \mathrm{~b}$ \\
\hline G14-AF & $18 \mathrm{c}$ & $26 \mathrm{~b}$ & $2 \mathrm{~d}$ & $20 \mathrm{c}$ & $762 \mathrm{a}$ & $6,290 \mathrm{a}$ \\
\hline Am-R & $4 \mathrm{~d}$ & $11 \mathrm{c}$ & $4 \mathrm{~d}$ & $5 \mathrm{~d}$ & $171 \mathrm{~b}$ & $1,480 \mathrm{c}$ \\
\hline Ad-R & $7 \mathrm{~d}$ & $10 \mathrm{c}$ & $6 \mathrm{~d}$ & $14 \mathrm{c}$ & $524 \mathrm{a}$ & $982 \mathrm{~d}$ \\
\hline G11-P & $39 \mathrm{~b}$ & $58 \mathrm{a}$ & $13 \mathrm{c}$ & $25 \mathrm{c}$ & $109 \mathrm{~b}$ & $2,916 \mathrm{~b}$ \\
\hline Ad-P & $61 \mathrm{a}$ & $15 \mathrm{~b}$ & $16 \mathrm{c}$ & $16 \mathrm{c}$ & $257 \mathrm{~b}$ & $4,479 \mathrm{~b}$ \\
\hline $\mathrm{Ce}$ & $11 \mathrm{c}$ & $17 \mathrm{~b}$ & $7 \mathrm{c}$ & $16 \mathrm{c}$ & $200 \mathrm{~b}$ & $2,949 \mathrm{~b}$ \\
\hline $\mathrm{Rc}$ & $74 \mathrm{a}$ & $69 \mathrm{a}$ & $76 \mathrm{a}$ & $41 \mathrm{~b}$ & $160 \mathrm{~b}$ & $261 \mathrm{e}$ \\
\hline $\mathrm{Gm}$ & $7 \mathrm{~d}$ & $52 \mathrm{a}$ & $6 \mathrm{c}$ & $43 \mathrm{~b}$ & $138 \mathrm{~b}$ & $591 \mathrm{~d}$ \\
\hline $\mathrm{M}-\mathrm{CN}$ & $44 \mathrm{~b}$ & $49 \mathrm{a}$ & $76 \mathrm{a}$ & $76 \mathrm{a}$ & $174 \mathrm{~b}$ & $1,800 \mathrm{~b}$ \\
\hline $\mathrm{M}-\mathrm{CV}$ & $60 \mathrm{a}$ & $66 \mathrm{a}$ & $77 \mathrm{a}$ & $46 \mathrm{~b}$ & $409 \mathrm{a}$ & $3,263 \mathrm{~b}$ \\
\hline $\mathrm{M}-\mathrm{AF}$ & $49 \mathrm{~b}$ & $53 \mathrm{a}$ & $82 \mathrm{a}$ & $44 \mathrm{~b}$ & $162 \mathrm{~b}$ & $4,465 \mathrm{~b}$ \\
\hline M-R & $59 a$ & $63 \mathrm{a}$ & $72 \mathrm{a}$ & $32 \mathrm{~b}$ & $262 \mathrm{~b}$ & $2,798 \mathrm{~b}$ \\
\hline M-P & $65 \mathrm{a}$ & $59 \mathrm{a}$ & $69 \mathrm{a}$ & $55 \mathrm{~b}$ & $253 \mathrm{~b}$ & $4,780 \mathrm{~b}$ \\
\hline MT & $74 \mathrm{a}$ & $55 \mathrm{a}$ & $77 \mathrm{a}$ & $60 \mathrm{a}$ & $314 \mathrm{a}$ & $3,211 \mathrm{~b}$ \\
\hline NI & - & - & - & - & - & - \\
\hline
\end{tabular}

*See table I for identification and origin. Means followed by the same letter belong to the same group by Scott-Knott test at $5 \%$.

isolates, which yielded a low level of colonization in this soil type. Mycorrhizal colonization by the G11-CN and G14-CN isolates from capoeira nova (young secondary forest) was intermediate to high in the second stage of the experiment, ranging from $54-60 \%$ in the Lavras soil and from $42-76 \%$ in the Amazon soil. However, the colonization level did not differ significantly between these fungal treatments compared to the isolate mixtures. Acaulospora delicata Ad-P was the only isolate that produced a high level of colonization in the Amazon soil, reaching $61 \%$ in stage 1 . However, this fungus colonized only $16 \%$ of roots in stage
2. Colonization by isolate G11-CV, from capoeira velha (old secondary forest), was not significantly different from that of the Ad-F isolate in the Amazon soil but achieved a value of $22-39 \%$ in the Lavras soil.

The mycorrhizal colonization by the fungal isolates from the UFLA collection tended to be higher in the Lavras soil than in the Amazon soil, with the exception of the Rc isolate, which reached a colonization level of $74-76 \%$ at both of the stages of the experiment in the Amazon soil (Table II). High levels of colonization were obtained with 
inoculation of artificial communities: $67 \%$ in Amazon soil and 55\% in Lavras soil.

The sporulation by fungal isolates differed between both soil types (Table II). In Amazon soil, sporulation ranged from 30 to 2,899 spores in 50 $\mathrm{mL}$ of soil (mean $=422$ spores), whereas in Lavras soil, sporulation varied from 261 to 10,645 spores in $50 \mathrm{~mL}$ of soil (mean $=3,309$ spores). Of the five isolates of $A$. delicata, Ad-CV, Ad-AF, and Ad-R isolates sporulated abundantly in the Amazon soil, whereas Ad-F and Ad-P had lower levels of sporulation. The Ad-AF isolate from agroforests produced the greatest number of spores in both of the soil types, ranging from 2,899 to 10,645 spores in $50 \mathrm{~mL}$ of soil. Of the Glomus sp.11 isolates, only the G11-CV from capoeira velha achieved a high spore numbers in Amazon soil (610 spores in $50 \mathrm{~mL}$ of soil). Isolates G11-CN and G11-AF from capoeira nova and agroforests, respectively, achieved low levels of sporulation, amounting to 30 and 40 spores in $50 \mathrm{~mL}$ of soil, respectively. Acaulospora morrowiae Am-CV isolate sporulated $67 \%$ more than A. morrowiae Am-R originated from farmlands in the Amazon soil. In general, sporulation tended to be higher in Lavras soil compared to Amazon soil. Isolate G11-CN in Lavras soil achieved a sporulation level of 8,510 spores in $50 \mathrm{~mL}$ of soil, which is approximately 284 times higher than the level found in the Amazon soil for the same isolate. Similarly, the sporulation of G11-AF in the Lavras soil was approximately 85 times greater than in the Amazon soil.

\section{PLANT RESPONSES TO MYCORRHIZATION}

Fungal treatment affected all variables assessed in stage 2 for both soil types. A significant effect on SDM production in Amazon soil was observed for all fungal treatments, and ranged from $233 \%$ to $622 \%$ increase compared to NI (Table III). Eighteen out of the 22 inoculation treatments yielded the highest production of SDM compared to NI, with an average increase of $511 \%$. In the Amazon soil, all artificial communities were among the treatments with the greatest capacity to increase cowpea growth.

Variation in growth after fungal inoculation was larger in Lavras soil, and four distinct groups was observed in this soil type. Only Am-CV did not differ significantly from NI, and the growth increments of the remaining isolates ranged from $308 \%$ to $950 \%$ (Table III). In the Lavras soil, 8 out of 22 inoculation treatments produced the highest increase in SDM, with a mean increase of $792 \%$ compared to NI. Among these treatments, isolates Ad-F, Ad-P, and Gm promoted SDM best increase in Lavras soil in relation Amazon soil. The smallest effects on SDM production were observed with $A$. delicata isolates (Ad-CV and Ad-R), which achieved a mean growth increase of $366 \%$ compared to NI. The effect of the isolate mixtures in the Lavras soil was much lower than that observed in the Amazon soil. The fungal isolates that had the greatest effect on growth, regardless of the soil type, were the Glomus isolates from capoeira nova (G11-CN and G14-CN) and Acaulospora isolate from farmlands $(\mathrm{Am}-\mathrm{R})$ in addition to the communities MR and MT.

Number of nodules in cowpea differed between soil types and was reduced in Amazon soil (Table III), where nodulation was only observed in seven treatments with fungal isolates (G14-CN, G11-P, MCN, MCV, MR, MP, and MT). In Lavras soil, nodulation was widespread among the fungal treatments, with an overall mean of 21 nodules per container. Plants inoculated with Am-CV and Ad-R isolates produced very low number of nodules that were not significantly different from NI plants.

Grain yield was influenced by fungal treatments in both the soil types (Fig. 1). Only the Ad-F isolate, which did not colonize cowpea in the Amazon soil, did not promote significant grain yield (Fig. 1). Non-inoculated plants grew very little and did not produce grains in either soil type. 
TABLE III

Shoot dry mass (SDM), nodules number (NN) and dry mass (NDM) of cowpea 85 days after harvest of stage 1, when diverse treatments of arbuscular mycorrhizal fungi were applied, and new planting (stage 2), in Amazon and Lavras soils.

\begin{tabular}{|c|c|c|c|c|c|c|}
\hline \multirow{3}{*}{ Treatments* } & \multicolumn{2}{|c|}{ SDM } & \multicolumn{2}{|c|}{$\mathrm{NN}$} & \multicolumn{2}{|c|}{ NDM } \\
\hline & Amazon soil & Lavras soil & Amazon soil & Lavras soil & Amazon soil & Lavras soil \\
\hline & \multicolumn{2}{|c|}{$\mathrm{g} \mathrm{pot}^{-1}$} & \multicolumn{2}{|c|}{ nodules pot ${ }^{-1}$} & \multicolumn{2}{|c|}{$m g \operatorname{pot}^{-1}$} \\
\hline Ad-F & $3.01 \mathrm{~b}$ & $3.20 \mathrm{a}$ & $0.0 \mathrm{~b}$ & $19.20 \mathrm{~b}$ & $0.0 \mathrm{~b}$ & $70.00 \mathrm{a}$ \\
\hline Ad-CV & $4.85 \mathrm{a}$ & $1.99 \mathrm{c}$ & $0.0 \mathrm{~b}$ & $9.20 \mathrm{c}$ & $0.0 \mathrm{~b}$ & $30.00 \mathrm{~b}$ \\
\hline $\mathrm{Am}-\mathrm{CV}$ & $5.49 \mathrm{a}$ & $0.85 \mathrm{~d}$ & $0.0 \mathrm{~b}$ & $2.20 \mathrm{~d}$ & $0.0 \mathrm{~b}$ & $0.00 \mathrm{c}$ \\
\hline G11-CV & $4.70 \mathrm{a}$ & $2.63 \mathrm{~b}$ & $0.0 \mathrm{~b}$ & $13.00 \mathrm{~b}$ & $0.0 \mathrm{~b}$ & $50.00 \mathrm{~b}$ \\
\hline G11-CN & $5.22 \mathrm{a}$ & $3.56 \mathrm{a}$ & $0.0 \mathrm{~b}$ & $26.20 \mathrm{a}$ & $0.0 \mathrm{~b}$ & $90.00 \mathrm{a}$ \\
\hline G14-CN & $4.48 \mathrm{a}$ & $3.35 \mathrm{a}$ & $11.20 \mathrm{a}$ & $9.40 \mathrm{c}$ & $50.00 \mathrm{a}$ & $40.00 \mathrm{~b}$ \\
\hline Ad-AF & $5.63 \mathrm{a}$ & $2.72 \mathrm{~b}$ & $0.0 \mathrm{~b}$ & $15.20 \mathrm{~b}$ & $0.0 \mathrm{~b}$ & $50.00 \mathrm{~b}$ \\
\hline G11-AF & $2.96 \mathrm{~b}$ & $2.95 \mathrm{~b}$ & $0.0 \mathrm{~b}$ & $16.40 \mathrm{~b}$ & $0.0 \mathrm{~b}$ & $60.00 \mathrm{~b}$ \\
\hline G14-AF & $5.41 \mathrm{a}$ & $2.53 \mathrm{~b}$ & $0.0 \mathrm{~b}$ & $18.00 \mathrm{~b}$ & $0.0 \mathrm{~b}$ & $20.00 \mathrm{c}$ \\
\hline Am-R & $5.69 \mathrm{a}$ & $3.99 \mathrm{a}$ & $0.0 \mathrm{~b}$ & $27.00 \mathrm{a}$ & $0.0 \mathrm{~b}$ & $110.00 \mathrm{a}$ \\
\hline Ad-R & $4.76 \mathrm{a}$ & $1.55 \mathrm{c}$ & $0.0 \mathrm{~b}$ & $5.00 \mathrm{~d}$ & $0.0 \mathrm{~b}$ & $10.00 \mathrm{c}$ \\
\hline G11-P & $6.04 \mathrm{a}$ & $2.28 \mathrm{~b}$ & $12.40 \mathrm{a}$ & $13.80 \mathrm{~b}$ & $30.00 \mathrm{a}$ & $20.00 \mathrm{c}$ \\
\hline Ad-P & $2.96 \mathrm{~b}$ & $3.24 \mathrm{a}$ & $0.0 \mathrm{~b}$ & $35.40 \mathrm{a}$ & $0.0 \mathrm{~b}$ & $90.00 \mathrm{a}$ \\
\hline $\mathrm{Ce}$ & $4.56 \mathrm{a}$ & $2.37 \mathrm{~b}$ & $0.0 \mathrm{~b}$ & $16.20 \mathrm{~b}$ & $0.0 \mathrm{~b}$ & $30.00 \mathrm{~b}$ \\
\hline $\mathrm{Rc}$ & $5.84 \mathrm{a}$ & $2.43 \mathrm{~b}$ & $0.0 \mathrm{~b}$ & $16.40 \mathrm{~b}$ & $0.0 \mathrm{~b}$ & $20.00 \mathrm{c}$ \\
\hline $\mathrm{Gm}$ & $3.33 \mathrm{~b}$ & $3.25 \mathrm{a}$ & $0.0 \mathrm{~b}$ & $33.60 \mathrm{a}$ & $0.0 \mathrm{~b}$ & $60.00 \mathrm{~b}$ \\
\hline $\mathrm{MCN}$ & $5.41 \mathrm{a}$ & $2.50 \mathrm{~b}$ & $1.60 \mathrm{~b}$ & $23.20 \mathrm{~b}$ & $0.00 \mathrm{~b}$ & $40.00 \mathrm{~b}$ \\
\hline $\mathrm{MCV}$ & $5.83 \mathrm{a}$ & $2.64 \mathrm{~b}$ & $19.40 \mathrm{a}$ & $20.60 \mathrm{~b}$ & $40.00 \mathrm{a}$ & $30.00 \mathrm{~b}$ \\
\hline MAF & $5.52 \mathrm{a}$ & $2.84 \mathrm{~b}$ & $0.0 \mathrm{~b}$ & $26.80 \mathrm{a}$ & $0.0 \mathrm{~b}$ & $50.00 \mathrm{~b}$ \\
\hline MR & $6.43 \mathrm{a}$ & $3.34 \mathrm{a}$ & $3.60 \mathrm{~b}$ & $45.60 \mathrm{a}$ & $10.00 \mathrm{~b}$ & $130.00 \mathrm{a}$ \\
\hline MP & $5.77 \mathrm{a}$ & $2.96 \mathrm{~b}$ & $3.00 \mathrm{~b}$ & $28.80 \mathrm{a}$ & $0.00 \mathrm{~b}$ & $50.00 \mathrm{~b}$ \\
\hline MT & $6.37 \mathrm{a}$ & $3.16 \mathrm{a}$ & $22.20 \mathrm{a}$ & $35.40 \mathrm{a}$ & $50.00 \mathrm{a}$ & $90.00 \mathrm{a}$ \\
\hline NI & $0.89 \mathrm{c}$ & $0.38 \mathrm{~d}$ & $0.0 \mathrm{~b}$ & $0.0 \mathrm{~d}$ & $0.0 \mathrm{~b}$ & $0.0 \mathrm{c}$ \\
\hline
\end{tabular}

* See table I for identification and origin. Means followed by the same letter belong to the same group by Scott-Knott test at $5 \%$.

Considering cowpea yield after 120 days of inoculation (stage 1), three classes of treatments is distinguished based on the grouping criteria after the Scott-Knott test (Fig. 1). High effectiveness treatments (bars with the letter "a") comprised 13 and 10 treatments in Amazon and Lavras soils, respectively, and included all artificial communities and the reference Gigaspora margarita (Gm) for both soils (Fig. 1). Isolates common to both soils in this group included Glomus G11-P, G14AF, originated from Pasture and Agroforestry, respectively. Medium effectiveness treatments (bars with the letter "b") comprised most of the remaining single isolates (Fig. 1). Rhizophagus clarus $(\mathrm{Rc})$ and C. etunicatum (Ce) were within the high effectiveness group in Amazon soil but at the medium effectiveness group in Lavras soil. Isolate Acaulospora delicata Ad-F was in the non-efficient treatment in Amazon soil but in the medium efficient treatment in Lavras soil (Fig. 1). Overall, $57 \%$ and $43 \%$ of the treatments in the Amazon and Lavras soils, respectively, were included in the high efficient treatment. On average, cowpea grain yield in this group increased by $65 \%$ compared to the medium efficient group in Amazon soil but only increased by $34 \%$ in Lavras soil. It was also 

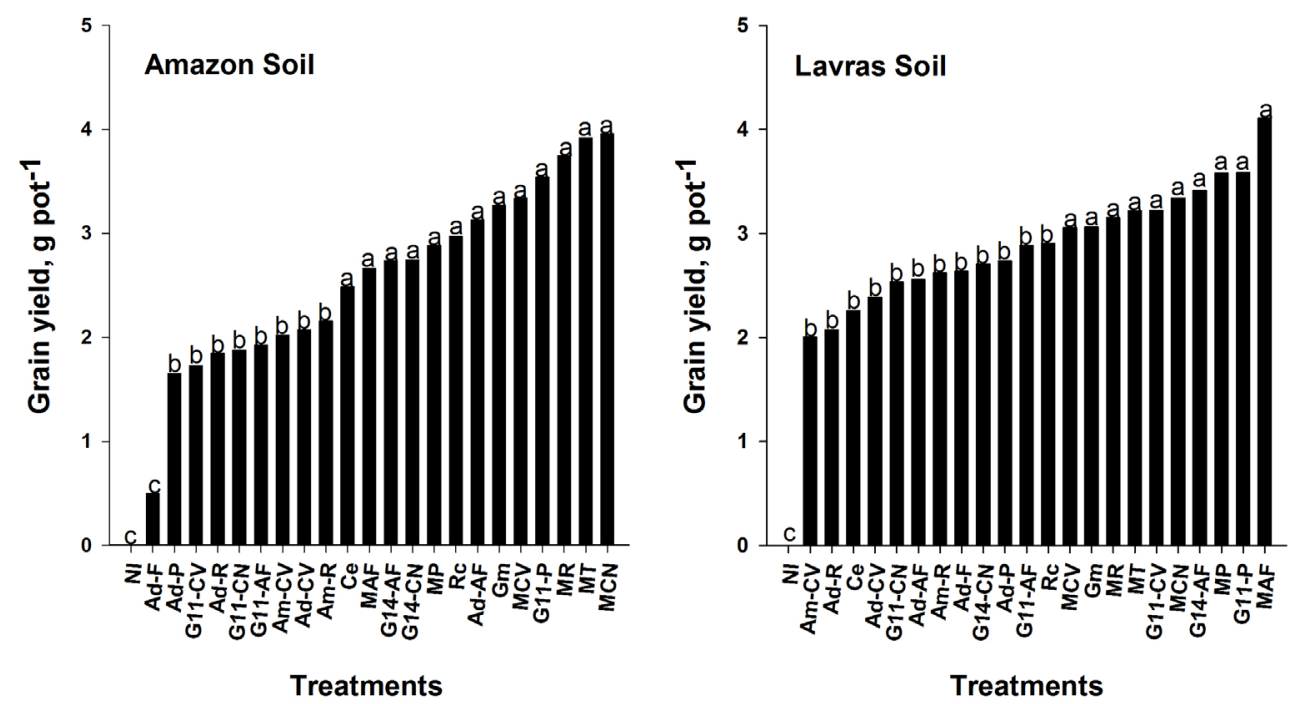

Figure 1 - Cowpea yields 120 day after inoculation (stage 1) with diverse treatments of arbuscular mycorrhizal fungi (see table I for AMF identification and origin), in Amazon and Lavras soils. Means followed by the same letter belong to the same group by Scott-Knott test at $5 \%$.

observed a significant and positive correlation between colonization rate and grain yield in cowpea in both of the soils ( $\mathrm{r}=0.58$ in the Amazon soil, $\mathrm{r}=0.61$ in the Lavras soil; both at $p \leq 0.01$ ).

\section{CONTENTS AND ACCUMULATION OF N AND P IN COWPEA}

There was a large variation in $\mathrm{N}$ content in SDM, from 17.92 to $58.52 \mathrm{~g} . \mathrm{kg}^{-1}$, and the largest content was found in the plants inoculated with $\mathrm{MCN}$ in the Amazon soil (Table IV). In the Lavras soil, the $\mathrm{N}$ contents in SDM were lower than in the Amazon soil, the highest $\mathrm{N}$ content in this soil of the Lavras, was obtained with isolate G11-CV. The benefits of AMF associated with $\mathrm{P}$ content were pronounced and widespread in the Amazon soil and were observed in all the treatments, with increases ranging from $33 \%$ to $149 \%$ compared with NI, and the mean P content was $1.15 \mathrm{~g} \cdot \mathrm{kg}^{-1}$. The highest contents were found in the plants inoculated with MCV, MR, Rc, MP, and G14-AF, and the levels reached $1.52 \mathrm{~g} . \mathrm{kg}^{-1}$, two times higher than those found in the NI group. In the Lavras soil, because of the low production of SDM in the NI group, it was not possible to determine the concentration of $\mathrm{P}$ in the control plants. In the inoculated plants, the mean $\mathrm{P}$ content was 0.90 g. $\mathrm{kg}^{-1}$.

The accumulation of $\mathrm{N}$ and $\mathrm{P}$ were higher in all inoculated treatments in Amazon soil than in Lavras soil. The $\mathrm{N}$ accumulation in the Amazon soil varied from 120.59 to $314.05 \mathrm{mg}$ of $\mathrm{N}$ per container, which was higher than that found in the Lavras soil (19.90 to $88.83 \mathrm{mg}$ of $\mathrm{N}$ per container). In the Amazon soil, the largest $\mathrm{P}$ contents were observed in the plants inoculated with Rc, MCV, $\mathrm{MR}$, and MP, with increases that ranged from 0.78 to 0.91 g. $\mathrm{kg}^{-1}$ compared to the NI group. In the Lavras soil, the highest accumulations of P in SDM were obtained in $68 \%$ of the treatments. In general, the accumulation of $\mathrm{P}$ in the Lavras soil was lower than that of the Amazon soil, with an average of $2.47 \mathrm{mg}$ of $\mathrm{P}$ per container, which was two times lower than that recorded in the Amazon soil (5.78 $\mathrm{mg}$ of $\mathrm{P}$ per container).

\section{DISCUSSION}

Studies aiming to select efficient AMF isolates for inoculation according to particular soil 
TABLE IV

Nitrogen (N) and Phosphorus (P) contents and accumulation in the shoot dry mass of cowpea 85 days after harvest of stage 1, when diverse arbuscular mycorrhizal fungi (see table I for identification and origin) were inoculated, and new planting (stage 2), in Amazon and Lavras soils.

\begin{tabular}{|c|c|c|c|c|c|c|c|c|}
\hline \multirow{3}{*}{ Treatments } & \multicolumn{4}{|c|}{ Nitrogen } & \multicolumn{4}{|c|}{ Phosphorus } \\
\hline & $\begin{array}{c}\text { Amazon } \\
\text { soil }\end{array}$ & $\begin{array}{c}\text { Lavras } \\
\text { soil }\end{array}$ & $\begin{array}{c}\text { Amazon } \\
\text { soil }\end{array}$ & $\begin{array}{c}\text { Lavras } \\
\text { soil }\end{array}$ & $\begin{array}{c}\text { Amazon } \\
\text { soil }\end{array}$ & $\begin{array}{c}\text { Lavras } \\
\text { soil }\end{array}$ & $\begin{array}{c}\text { Amazon } \\
\text { soil }\end{array}$ & $\begin{array}{c}\text { Lavras } \\
\text { soil }\end{array}$ \\
\hline & \multicolumn{2}{|c|}{$\mathrm{g} \mathrm{kg}^{-1}$} & \multicolumn{2}{|c|}{$\mathrm{mg}$ pot $^{-1}$} & \multicolumn{2}{|c|}{$\mathrm{g} \mathrm{kg}^{-1}$} & \multicolumn{2}{|c|}{$\mathrm{mg} \mathrm{pot}^{-1}$} \\
\hline Ad-F & $49.84 \mathrm{~b}$ & $25.76 \mathrm{~b}$ & $140.27 \mathrm{c}$ & $83.38 \mathrm{a}$ & $0.99 \mathrm{c}$ & $0.91 \mathrm{~b}$ & $2.85 \mathrm{~d}$ & $2.89 \mathrm{a}$ \\
\hline Ad-CV & $39.20 \mathrm{c}$ & $23.52 \mathrm{c}$ & $187.06 \mathrm{~b}$ & $48.84 \mathrm{c}$ & $0.91 \mathrm{~d}$ & $1.05 \mathrm{a}$ & $4.43 \mathrm{c}$ & $2.11 \mathrm{~b}$ \\
\hline Am-CV & $36.12 \mathrm{~d}$ & $23.80 \mathrm{c}$ & $197.48 \mathrm{~b}$ & $19.90 \mathrm{~d}$ & $0.91 \mathrm{~d}$ & $0.92 \mathrm{~b}$ & $4.99 \mathrm{c}$ & $0.78 \mathrm{c}$ \\
\hline G11-CV & $40.88 \mathrm{c}$ & $33.88 \mathrm{a}$ & $184.58 \mathrm{~b}$ & $88.83 \mathrm{a}$ & $1.09 \mathrm{c}$ & $1.01 \mathrm{a}$ & $5.08 \mathrm{c}$ & $2.65 \mathrm{a}$ \\
\hline G11-CN & $39.76 \mathrm{c}$ & $18.48 \mathrm{c}$ & $204.35 \mathrm{~b}$ & $65.21 \mathrm{~b}$ & $1.09 \mathrm{c}$ & $0.91 \mathrm{~b}$ & $5.77 \mathrm{~b}$ & $3.23 \mathrm{a}$ \\
\hline G14-CN & $33.32 \mathrm{~d}$ & $21.00 \mathrm{c}$ & $144.43 \mathrm{c}$ & $69.51 \mathrm{~b}$ & $1.17 \mathrm{c}$ & $0.81 \mathrm{c}$ & $5.32 \mathrm{c}$ & $2.73 \mathrm{a}$ \\
\hline Ad-AF & $33.88 \mathrm{~d}$ & $21.84 \mathrm{c}$ & $184.58 \mathrm{~b}$ & $59.32 \mathrm{~b}$ & $1.09 \mathrm{c}$ & $1.06 \mathrm{a}$ & $6.18 \mathrm{~b}$ & $2.85 \mathrm{a}$ \\
\hline G11-AF & $45.36 \mathrm{~b}$ & $22.96 \mathrm{c}$ & $131.83 \mathrm{c}$ & $67.23 \mathrm{~b}$ & $1.22 \mathrm{~b}$ & $0.98 \mathrm{a}$ & $3.56 \mathrm{~b}$ & $2.90 \mathrm{a}$ \\
\hline G14-AF & $36.96 \mathrm{~d}$ & $23.24 \mathrm{c}$ & $198.62 \mathrm{~b}$ & $58.66 \mathrm{~b}$ & $1.37 \mathrm{a}$ & $1.02 \mathrm{a}$ & $7.33 \mathrm{~b}$ & $2.64 \mathrm{a}$ \\
\hline Am-R & $35.00 \mathrm{~d}$ & $21.84 \mathrm{c}$ & $198.27 \mathrm{~b}$ & $87.09 \mathrm{a}$ & $1.01 \mathrm{c}$ & $0.94 \mathrm{~b}$ & $5.73 \mathrm{~b}$ & $3.77 \mathrm{a}$ \\
\hline Ad-R & $39.48 \mathrm{c}$ & $18.76 \mathrm{c}$ & $184.04 \mathrm{~b}$ & $29.72 \mathrm{~d}$ & $1.09 \mathrm{c}$ & $0.95 \mathrm{~b}$ & $5.27 \mathrm{c}$ & $1.46 \mathrm{c}$ \\
\hline G11-P & $32.20 \mathrm{~d}$ & $27.44 \mathrm{~b}$ & $188.53 \mathrm{~b}$ & $63.93 \mathrm{~b}$ & $1.10 \mathrm{c}$ & $0.83 \mathrm{c}$ & $6.65 \mathrm{~b}$ & $1.90 \mathrm{~b}$ \\
\hline Ad-P & $47.60 \mathrm{~b}$ & $19.04 \mathrm{c}$ & $127.45 \mathrm{c}$ & $61.72 \mathrm{~b}$ & $1.09 \mathrm{c}$ & $0.78 \mathrm{c}$ & $3.20 \mathrm{~b}$ & $2.50 \mathrm{a}$ \\
\hline $\mathrm{Ce}$ & $36.96 \mathrm{~d}$ & $20.16 \mathrm{c}$ & $163.13 \mathrm{c}$ & $46.57 \mathrm{c}$ & $0.98 \mathrm{c}$ & $0.82 \mathrm{c}$ & $4.44 \mathrm{c}$ & $1.97 \mathrm{~b}$ \\
\hline $\mathrm{Rc}$ & $28.56 \mathrm{e}$ & $24.08 \mathrm{c}$ & $161.76 \mathrm{c}$ & $58.08 \mathrm{~b}$ & $1.39 \mathrm{a}$ & $0.87 \mathrm{c}$ & $8.09 \mathrm{a}$ & $2.10 \mathrm{~b}$ \\
\hline $\mathrm{Gm}$ & $46.76 \mathrm{~b}$ & $20.16 \mathrm{c}$ & $153.09 \mathrm{c}$ & $66.77 \mathrm{~b}$ & $1.28 \mathrm{~b}$ & $0.78 \mathrm{c}$ & $4.22 \mathrm{c}$ & $2.54 \mathrm{a}$ \\
\hline $\mathrm{MCN}$ & $58.52 \mathrm{a}$ & $20.44 \mathrm{c}$ & $314.05 \mathrm{a}$ & $49.36 \mathrm{c}$ & $1.20 \mathrm{~b}$ & $0.80 \mathrm{c}$ & $6.41 \mathrm{~b}$ & $1.99 \mathrm{~b}$ \\
\hline $\mathrm{MCV}$ & $26.04 \mathrm{e}$ & $19.60 \mathrm{c}$ & $153.32 \mathrm{c}$ & $51.76 \mathrm{c}$ & $1.52 \mathrm{a}$ & $0.92 \mathrm{~b}$ & $8.79 \mathrm{a}$ & $2.43 \mathrm{a}$ \\
\hline MAF & $21.84 \mathrm{e}$ & $20.72 \mathrm{c}$ & $120.59 \mathrm{c}$ & $58.95 \mathrm{~b}$ & $1.15 \mathrm{c}$ & $0.90 \mathrm{~b}$ & $6.36 \mathrm{~b}$ & $2.53 \mathrm{a}$ \\
\hline MR & $34.72 \mathrm{~d}$ & $17.92 \mathrm{c}$ & $220.09 \mathrm{~b}$ & $59.33 \mathrm{~b}$ & $1.44 \mathrm{a}$ & $0.91 \mathrm{~b}$ & $9.25 \mathrm{a}$ & $3.04 \mathrm{a}$ \\
\hline MP & $24.08 \mathrm{e}$ & $17.92 \mathrm{c}$ & $137.22 \mathrm{c}$ & $53.51 \mathrm{c}$ & $1.38 \mathrm{a}$ & $0.85 \mathrm{c}$ & $7.97 \mathrm{a}$ & $2.51 \mathrm{a}$ \\
\hline MT & $26.32 \mathrm{e}$ & $21.00 \mathrm{c}$ & $168.35 \mathrm{c}$ & $65.83 \mathrm{~b}$ & $0.81 \mathrm{~d}$ & $0.90 \mathrm{~b}$ & $5.18 \mathrm{c}$ & $2.83 \mathrm{a}$ \\
\hline NI & $-*$ & $-*$ & $-*$ & $-*$ & $0.61 \mathrm{e}$ & $-* *$ & $0.40 \mathrm{e}$ & $-* *$ \\
\hline
\end{tabular}

* and ** insufficient material or determination of nitrogen and phosphorus, respectively. Means followed by the same letter belong to the same group by Scott-Knott test at $5 \%$.

conditions and crops involve culturing these fungi in single cultures and screening them for plant growth and nutrition promotion under controled conditions (Abbott and Robson 1982). These procedures were adopted in the present study by focusing in screening fungal isolates originated from communities previously tested for their effectiveness in promoting growth and nutrition of cowpea. Our results evidenced i) the presence of high efficient fungi originating from distinct land use types, suggesting that fungal origin is not a determinant of a fungus and effectiveness, and ii) effectiveness of a given fungal isolate was conserved among both soil types tests.

Mycorrhizal root colonization levels was stable within the same fungal isolate growing in both soil types. For example, root colonization of Acaulospora delicata (Ad) and A. morrowiae (Am) from capoeira velha $(\mathrm{CV})$ was always $\leq 6 \%$ in both soil types. Furthermore, intraspecific variability in root colonization was observed in the present study: isolates from the same species (e.g., G11 and Ad) 
exhibited low $(<10 \%)$ to high $(>25 \%)$ colonization rates. This result suggests that fungal growth within the root system may be determined by intrinsic factors of the fungal isolates (Munkvold et al. 2004, Koch et al. 2004). The range of mycorrhizal colonization in cowpea reported in the present study was quite high but was within the range previously observed for this species. Muthukumar and Udaiyan (2002) reported colonization rates of cowpea greater than $60 \%$, whereas Rohyadi et al. (2004), under soil acid conditions ( $\mathrm{pH} 4.7$ ), reported a colonization rate of $35 \%$. Among the reference isolates, Gigaspora margarita (Gm) yielded a low colonization rate in Amazon soil and a high colonization rate in Lavras soil, which may reflect local adaptation of this fungus to this soil condition as this isolate is originated from the same region where the Lavras soil was collected. A metaanalysis of studies published between 1988 and 2003 by Lekberg and Koide (2005) reported that an increase in mycorrhizal colonization resulted in an average increase of $23 \%$ in plant yield in the field. This change may be of particular importance in the Amazon region, where soils in deforested areas rapidly lose fertility and the strategy to maintain plant production to sustain local population is to advance deforestation to new areas. It is essential to find alternative strategies capable of enhancing plant nutrition and health, thereby ensuring plant production, reducing deforestation pressure and thus leading to the sustainability of agricultural systems. In this context, the identification of efficient AMF isolates capable of improving crop yield is of great interest to ensure food safety in the Amazon region.

The spore production by the AMF isolates in Lavras soil tended to be higher than that observed in the Amazon soil, indicating that chemical and physical soil characteristics impact fungal reproductive strategy via asexual spores in these fungi. The Amazon soil was clayey and very cohesive when dry and exhibited a low porosity, which may have contributed to a lower sporulation level, considering that clayey soils tend to impact negatively upon AMF spore densities (Sieverding 1991). In the present study, the number of spores from isolates of the same species varied considerably depending on its origin and type of soil. For example, isolate G11-CN in the Lavras soil had a sporulation level 284 times greater than the level found in the Amazon soil, despite the origin of this fungus was from an Amazonian soil. Among the isolates of Glomus sp.11 and A. morrowiae, only the G11-CV and Am-CV isolates, both from capoeira velha, had a high sporulation level in the Amazon soil. These results suggest that AMF can rapidly undergo genotypic changes that influence their fitness (in this case, measured by the sporulation level), according to the environmental conditions in which they are cultivated (Angelard et al. 2014). Because of these changes, the effectiveness of an isolate tested under controlled conditions can change rapidly under field conditions, and this variability should be considered when choosing AMF isolates for selection programs.

Single (a single AMF isolate) and multiple (artificial communities) inoculation were able to stimulate the growth and yield of cowpea, although to different degrees. Am-CV was the only isolate that failed to promote growth in the Lavras soil compared to NI plants. Similarly, Ad-F was the only isolate that had no significant effect on grain yield in the Amazon soil, which can be explained by the absence of plant colonization by this isolate in this soil. This generalized response of cowpea to AMF has been well documented (Almeida et al. 1985, Rohyadi et al. 2004), and the beneficial effects of AMF are attributed mostly to the enhancement of plant nutrition (Koide 1991, Smith et al. 1992), especially considering $\mathrm{P}$ uptake from the soil. Some isolates, including G11-P, G11-CV, Ad-AF, G14-CN, G14-AF, and the artificial communities increased 2.5 to 3.0 times the grain yield of cowpea compared to NI plants. These results indicate a large 
effectiveness of AMF originating from distinct land uses in the western Amazon soils and the presence of highly efficient isolates in mycorrhizal communities, which can be considered promising for future studies of the application of AMF to production systems in the Amazon region. Notably, the most promising isolates were originated from areas with different land uses, for example, G14$\mathrm{CN}$ and G14-AF were isolated from areas occupied by capoeira nova and agroforests, respectively.

To determine the reasons for the poor nodulation in the Amazon soil, an additional test was conducted using unsterilized Amazon soil to verify whether the low nodulation level was associated with soil sterilization, considering that the clayey texture of this soil type may have contributed to a residual effect of the sterilizing agent. The nodule formation in sterilized and unsterilized soils followed the same pattern: a few small nodules, and most of the fungal treatments did not yield any nodulation (data not shown). Therefore, methyl bromide did not influence the formation of nodules in the samples evaluated. Moreover, the lower nodulation level in the Amazon soil in comparison with the Lavras soil might be derived from the soil characteristics - clayey texture, low porosity, and low water infiltration-resulting in reduced aeration, thus hindering the development of nodules and consequently reducing biological nitrogen fixation.

The content and accumulation of shoots $\mathrm{N}$ and $\mathrm{P}$ in differed markedly among fungal treatments. In Amazon soil, all the fungal treatments that produced the highest contents of $\mathrm{N}$ resulted in the lowest increases in SDM compared to NI, except to that was in plants inoculated with $\mathrm{MCN}$, indicating a concentration effect for those treatments with lowest SDM and highest $\mathrm{N}$ content. The isolate of $R$. clarus and the artificial communities MCV, MAF, MP, and MT were the fungal treatments that yielded the lowest shoot $\mathrm{N}$ content of cowpea in the Amazon soil. This pattern most likely resulted from the effect of dilution because all of these fungal treatments are among the treatments that promoted the highest production of SDM. This dilution effect on mycorrhized plants has been observed in soybeans (Paula et al. 1988), in various tree species (Flores-Aylas et al. 2003), and in cowpea (Silva et al. 2009).

The results indicate a large variability among the fungal isolates in the uptake of $\mathrm{P}$, particularly in the Amazon soil, where 4 distinct groups were found. Although a direct relationship between the increase in SDM and P content from the soil can not be established, it appears that all the treatments in which inoculation increased SDM resulted in increased P levels in the plant, a fact that has been previously reported (Sanni 1976, Islan et al. 1980, Almeida et al. 1985, Rohyadi et al. 2004, Silva et al. 2009). Isolates efficient in absorbing $P$ can reduce $\mathrm{P}$ deficits through increased absorption and increased P use by plants (Koide 1991) and by enhancing plant colonization by these fungi (Smith et al. 1992).

Inoculation with artificial communities, including MP, MR, and MCV, was most effective in increasing cowpea $\mathrm{P}$ levels and promoting growth and grain yield of cowpea in the Amazon soil. These results confirm to some extent those found by Santos et al. (2008), who used AMF isolates from bauxite-mining soils in the early growth of native plant species. These authors observed that isolate mixtures exhibited the greatest effectiveness in increasing plant growth compared to the noninoculated control. However, in the present study, the isolates G11-CN, G14-CN, and Am-R also exerted strong effects on growth, irrespective of the growth conditions. These results corroborate those found by Daft and Hogarth (1983) and Edathil et al. (1996), indicating that the maximum benefits for growth can be achieved using a single and efficient AMF species and that isolate mixtures composed of a high diversity of species do not necessarily translate into increased benefits to plants. 
The large inter- and intraspecific effectiveness of AMF tested in the present study is of great importance for controled inoculation programs in Amazon soils. Among the isolates tested, the most promising for cowpea were those from the genus Glomus. Considering that this genus is quite abundant, diverse, and adapts easily to different soil conditions, species of this genus should be prioritized when selecting fungal isolates to efficiently inoculate crops of interest in the Amazon region. Studies aimed at establishing the relationship between functional diversity and benefits to plants are essential and will help elucidate the relationship between biodiversity and ecosystem functioning. Considering the large extent and variation of Amazon ecosystems, this study contributes to the understanding of the functional diversity of AMF in the Alto Solimões region in the state of Amazonas and provides useful information for the exploitation of these important genetic resources in the Amazon biome.

\section{ACKNOWLEDGMENTS}

This manuscript presents part of the findings of the international project "Conservation and Management of Below-Ground Biodiversity" (CSM-BGBD) implemented in seven tropical countries - Brazil, Cote d'Ivoire, India, Indonesia, Kenya, Mexico, and Uganda. This project is coordinated by the Tropical Soil Biology and Fertility Institute of CIAT (TSBF-CIAT) with cofinancing from the Global Environmental Facility (GEF), and implementation support from the United Nations Environment Program (UNEP). Views expressed in this publication are those of their authors and do not necessary reflect those of the authors organization, the UNEP and the GEF. The Brazilian component of the CSM-BGBD project is called Bios Brasil and is coordinated by UFLA (www.biosbrasil.ufla.br). We thank the Conselho Nacional de Desenvolvimento
Científico e Tecnológico (CNPq) for research productivity fellowships and grant (J.O. Siqueira, S. Stürmer, F.M.S. Moreira) and Coordenação de Aperfeiçoamento de Pessoal de Nível Superior (Capes) for student fellowship.

\section{REFERENCES}

ABBOTT LK AND ROBSON AD. 1982. The role of vesicular-arbuscular mycorrhizal fungi in agriculture and the selection of fungi for inoculation. Aust J Agri Res 33: 389-408.

ALMEIDA RT, VASCONCELOS I AND SABADIA FRB. 1985. Efeito da infecção de fungos micorrízicos VA em feijão-de-corda, Vigna unguiculata (L.) Walp. Rev Ciênc Agron 16: 23-26.

ANGELARD C, TANNER CJ, FONTANILLA P, NICULITAHIRZEL H, MASCLAUX F AND SANDERS IR. 2014. Rapid genotypic change and plasticity in arbuscular mycorrhizal fungi is caused by a host shift and enhanced by segregation. ISME J 8: 284-294.

ANTUNES PM, KOCH AM, MORTON JB, RILLIG MC AND KLIRONOMOS JN. 2011. Evidence for functional divergence in arbuscular mycorrhizal fungi from contrasting climatic origins. New Phytol 189: 507-514.

DAFT MJ AND HOGARTH BG. 1983. Competitive interactions amongst four species of Glomus on maize and onion. Trans Br Mycol Soc 80: 339-345.

EDATHIL TT, MANIAN S AND UDAIYAN K. 1996. Interaction of multiple VAM fungal species on root colonization, plant growth and nutrient status of tomato seedlings (Lycopersicon esculentum Mill.). Agric Ecosyst Environ 59: 63-68.

FERREIRA DF. 2011. Sisvar: a computer statistical analysis system. Ciênc Agrotec 35: 1039-1042.

FLORES-AYLAS WW, SAGGIN-JÚNIOR OJ, SIQUEIRA JO AND DAVID AC. 2003. Efeito de Glomus etunicatum e fósforo no crescimento inicial de espécies arbóreas em semeadura direta. Pesq Agropec Bras 38: 257-266.

FREITAS RD, BUSCARDO E, NAGY L, MACIEL ABD, CARRENHO R AND LUIZAO RCC. 2014. Arbuscular mycorrhizal fungal communities along a pedohydrological gradient in a Central Amazonian terra firme forest. Mycorrhiza 24: 21-32.

GERDEMANN JW AND NICOLSON TH. 1963. Spores of mycorrhizal endogone species extracted from soil wet sieving and decanting. Trans Br Mycol Soc 46: 235-244.

GIANINAZZI S, GOLLOTTE A, BINET M-N, VAN TUINEN D, REDECKER D AND WIPF D. 2010. Agroecology: the key role of arbuscular mycorrhizas in ecosystems services. Mycorrhiza 20: 519-530. 
GIOVANNETTI M AND MOSSE B. 1980. An evaluation of techniques to measure vesicular-arbuscular mycorrhizal infection on roots. New Phytol 84: 489-500.

HOAGLAND DR AND ARNON DI. 1950. The water culture method of growing plants without soil, California Experiment Station, Circular No. 347. The College of Agriculture, University of California, Berkeley, 32 p.

ISLAN R, AYANABA A AND SANDERS FE. 1980. Response of cowpea (Vigna unguiculata) to inoculation with VA: mycorrhizal fungi and to rock phosphate fertilization in some unsterilized Nigerian soils. Plant Soil 54: 107-117.

JANSA J, SMITH FA AND SMITH SE. 2008. Are there benefits of simultaneous root colonization by different arbuscular mycorrhizal fungi? New Phytol 177: 779-789.

KLIRONOMOS JN. 2003. Variation in plant response to native and exotic arbuscular mycorrhizal fungi. Ecology 84: 2292-2301.

KOCH AM, KUHN G, FONTANILLAS P, FUMAGALLI L, GOUDET J AND SANDERS IR. 2004. High genetic variability and low local diversity in an arbuscular mycorrhizal fungal population. Proc Nat Acad Sci USA 101: 2369-2374.

KOIDE RT. 1991. Nutrient supply, nutrient demand and plant response to mycorrhizal infection. New Phytol 117: 365386.

LEAL PL, STÜRMER SL AND SIQUEIRA JO. 2009. Occurrence and diversity of arbuscular mycorrhizal fungi in trap cultures from soils under different land use systems in the Amazon. Braz J Microbiol 40: 111-121.

LEAL PL, STÜRMER SL AND SIQUEIRA JO. 2013. Switch of tropical Amazon forest to pasture affects taxonomic composition but not species abundance and diversity of arbuscular mycorrhizal fungal community. App Soil Ecol 71: 72-80.

LEKBERG Y AND KOIDE RT. 2005. Is plant performance limited by abundance of arbuscular mycorrhizal fungi? A meta-analysis of studies published between 1988 and 2003. New Phytol 168: 189-204.

MENSAH JA, KOCH AM, ANTUNES PM, KIERS, ET, HART M AND BÜCKING H. 2015. High functional diversity within species of arbuscular mycorrhizal fungi is associated with differences in phosphate and nitrogen uptake and fungal phosphate metabolism. Mycorrhiza 25: 533-546.

MOREIRA FMS, NÓBREGA RSA, JESUS EC, FERREIRA DF AND PÉREZ DV. 2009. Differentiation in the fertility of Inceptisols as related to land use in the upper Solimões river region, western Amazon. Sci Total Environ 408: 349355.

MUNKVOLD L, KJOLLER R, VESTBERG M, ROSENDAHL S AND JAKOBSEN I. 2004. High functional diversity within species of arbuscular mycorrhizal fungi. New Phytol 164: 357-364.

MUTHUKUMAR T AND UDAIYAN K. 2002. Growth and yield of cowpea as influenced by changes in arbuscular mycorrhiza in response to organic manuring. J Agron Crop Sci 88: 123-132.

PAULA MA, SIQUEIRA JO, OLIVEIRA LH AND OLIVEIRA E. 1988. Efetividade simbiótica relativa em soja de população de fungos endomicorrízicos nativos e de isolados de Glomusma crocarpum e Gigaspora margarita. Rev Bras Ciênc Solo 12: 25-31.

PHILLIPS JM AND HAYMAN DS. 1970. Improved procedures for clearing roots and staining parasitic and vesicular arbuscular mycorrhizal fungi for rapid assessment of infection. Trans Br Mycol Soc 55: 158-161.

ROHYADI A, SMITH FA, MURRAY RS AND SMITH SE. 2004. Effects $\mathrm{pH}$ on mycorrhizal colonisation and nutrient uptake in cowpea under conditions that minimise confounding effects of elevated available aluminium. Plant Soil 260: 283-290.

SANNI SO. 1976. Vesicular-arbuslar mycorrhiza in some Nigerian soils and their effect on the growth of cowpea (Vigna unguiculata), tomato (Lycopersicon esculentum) and maize (Zea mays). New Phytol 77: 667-671.

SANTOS JGD, SIQUEIRA JO AND MOREIRA FMS. 2008. Eficiência de fungos micorrízicos arbusculares isolados de solos de áreas de mineração de bauxita no crescimento inicial de espécies nativas. Rev Bras Ciênc Solo 32: 141150.

SIEVERDING E. 1991. Vesicular-arbuscular mycorrhiza management in tropical agrosystems. Eschborn, Fed. Rep. of Germany: Fried land Bremer, $371 \mathrm{p}$.

SILVA GA, SIQUEIRA JO AND STÜRMER SL. 2009. Eficiência de fungos micorrízicos arbusculares isolados de solos sob diferentes sistemas de uso na região do Alto Solimões na Amazônia. Acta Amaz 39: 477-488.

SIQUEIRA JO, SAGGIN-JÚNIOR OJ, FLORES-AYLAS WW AND GUIMARÃES PTG. 1998. Arbuscular mycorrhizal inoculation and superphosphate application influence plant development and yield of coffee in Brazil. Mycorrhiza 7: 293-300.

SMITH FA, JAKOBSEN I AND SMITH SE. 2000. Spatial differences in acquisition of soil phosphate between two arbuscular mycorrhiza fungi in symbiosis with Medicago truncatula. New Phytol 147: 357-366.

SMITH SE AND READ DJ. 2008. Mycorrhizal Symbiosis, $3^{\text {rd }}$ ed., London: Academic Press, 785 p.

SMITH SE, ROBSON AD AND ABBOTT LK. 1992. The involvement of mycorrhizas in assessment of genetically dependent efficiency of nutrient uptake and use. Plant Soil 146: 169-179.

SMITH SE, SMITH FA AND JAKOBSEN I. 2004. Functional diversity in arbuscular mycorrhizal (AM) symbioses: the 
contribution of the mycorrhizal P uptake pathway is not correlated with mycorrhizal responses in growth or total $\mathrm{P}$ uptake. New Phytol 162: 511-524.

STÜRMER SL. 2004. Efeito de diferentes isolados fúngicos da mesma comunidade micorrízica no crescimento e absorção de fósforo em soja e trevo vermelho. Rev Bras Ciênc Solo 28: 611-622.

STÜRMER SL AND SIQUEIRA JO. 2011. Species richness and spore abundance of arbuscular mycorrhizal fungi across distinct land uses in western Brazilian Amazon. Mycorrhiza 21: 255-267.
THONAR C, SCHNEPF A, FROSSARD E, ROOSE T AND JANSA J. 2011. Traits related to differences in function among three arbuscular mycorrhizal fungi. Plant Soil 339: 231-245.

VAN DER HEIJDEN MGA, KLIRONOMOS JN, URSIC M, MOUTOGLIS P, STREITWOLF-ENGEL R, BOLLER T, WIEMKEN A AND SANDERS IR. 1998. Mycorrhizal fungal diversity determines plant biodiversity, ecosystem variability and productivity. Nature 396: 69-72.

ZAROSKY RJ AND BURAU RGA. 1977. Rapid nitric perchloric acid digestion method for multi element tissue analysis. Commun Soil Sci Plant Anal 8: 425-436. 